\title{
Islamic securities (șukūk) and economic growth: New empirical investigation from Southeast Asia using non-parametric analysis of MCMC panel quantile regression
}

\author{
Mohammed Ayoub Ledhem and Mohammed Mekidiche \\ Department of Economics, University Centre of Maghnia, Maghnia, Algeria
}

\begin{abstract}
Purpose - This paper aims to investigate empirically whether Islamic securities enhance economic growth in the Southeast Asian region based on the endogenous growth theory using the non-parametric analysis. Design/methodology/approach - This paper applies panel quantile regression with Markov chain Monte Carlo optimization as an optimal non-parametric approach to investigate the effect of Islamic securities on economic growth starting from 2013Q4 to 2019Q4 in Southeast Asia. Total issued Islamic securities holdings are employed as a measure for Islamic securities, while the gross domestic product is employed as a proxy for economic growth. The sample includes all working Islamic financial foundations in the top progressive Islamic securities markets' countries of Southeast Asia (Malaysia, Indonesia and Brunei Darussalam).

Findings - The findings confirm that the increase of issuing Islamic securities in Islamic capital markets of Southeast Asia is increasing the levels of economic growth, reflecting the weighty role of the Islamic capital market development as an active contributor to economic growth.

Practical implications - This research would fill the literature gap by exploring Islamic securities-economic growth nexus in Southeast Asia using a robust non-parametric approach based on the endogenous growth theory for better estimation results. The findings of this review serve as a roadmap for financial analysts, policymakers and decision makers to stimulate the Islamic securities markets as another source of finance which can promote the economic growth.

Originality/value - This research is the first that investigates empirically the Islamic securities-economic growth nexus in Southeast Asia using a new empirical investigation built on the non-parametric analysis and outlined within the theoretical context of the endogenous growth model to gain robust evidence about this nexus.
\end{abstract}

Keywords Islamic securities (șkūk), Economic growth, Islamic capital markets, Endogenous growth theory, Panel quantile regression, Markov chain Monte Carlo (MCMC) optimization

Paper type Research paper

\section{JEL Classification - C31, G15, F43, O47. KAUJIE Classification - H52, I73, K16}

(C) Mohammed Ayoub Ledhem and Mohammed Mekidiche. Published in Islamic Economic Studies. Published by Emerald Publishing Limited. This article is published under the Creative Commons Attribution (CCBY 4.0) licence. Anyone may reproduce, distribute, translate and create derivative works of this article (for both commercial and non-commercial purposes), subject to full attribution to the original publication and authors. The full terms of this licence may be seen at http://creativecommons. org/licences/by/4.0/legalcode

The authors would like to thank the General Directorate of Scientific Research and Technological Development "La Direction Générale de la Recherche Scientifique et du Développement Technologique (DGRSDT)" under the Algerian Ministry of Higher Education and Scientific Research "le Ministerre de l'Enseignement Supérieur et la Recherche Scientifique (Algerie)" for supporting this research. The authors would also like to thank the Laboratory for Money and Financial Institutions in the Arab Maghreb "MIFMA Laboratory" (Algeria) for the continuous support of research.

Islamic securities (sukūk) and economic growth

Received 25 June 2021 Revised 4 October 2021 Accepted 14 November 2021 
IES

29,2

\section{Introduction}

Islamic finance has recently turned out to be a significant player in economic development around the world and is expected to grow to US $\$ 3.8$ trillion by 2023 due to the expansion of its reserves (Reuters, 2020). Islamic securities are currently the key Islamic finance mechanism that enhances economic development, according to Lahsasna et al. (2018) and Al-Ali (2019). Islamic debt securities or sukūk are certificates of Islamic bonds that conform with Islamic laws under which sukūk's benefit is interest-free but is generated from the underlying asset value (Lahsasna et al., 2018; Al-Ali, 2019). The benefit derived from Islamic securities is therefore not interest-based but it is a consequence of the basic asset's efficiency.

Lately, particularly in most Muslim economies, the Islamic securities market has seen massive growth. Therefore, in Southeast Asia, where the Islamic finance sector is advanced in all of Malaysia, Indonesia and Brunei Darussalam as stated by Ledhem and Mekidiche (2021), the global pioneer Islamic securities markets are in Southeast Asia (Reuters, 2020). According to Haini (2019), owing to developments in the capital markets, Southeast Asia has recently undergone tremendous economic growth. Because the Islamic securities markets are part of the financial markets, there is a controversy over whether the funding of Islamic securities facilitates the economic growth of Southeast Asia. For this purpose, this study aims to explore whether Islamic securities enhance the economic growth of Southeast Asia as an extension of the literature on the relationship between Islamic securities and economic growth.

In line with Haini (2019), the financial market development in Southeast Asia is promoting economic growth. Furthermore, the Islamic financial markets of Islamic securities are part of the financial markets, and for the reason that Islamic securities markets promote economic growth globally, this paper expresses the hypothesis as the following:

(1) Islamic securities positively affect economic growth in Southeast Asia.

Over the last few years, Southeast Asia witnessed an enormous development in Islamic securities markets, by setting up $50.5 \%$ of the global Islamic securities issue. Malaysia remained dominant on the global Islamic securities market and retained its ranking as the world's top issuer with $41 \%$ of the total global Islamic securities' share in the first semester of 2018, an increase of $33 \%$ a year earlier (IIFMSukuk Report, 2019, 2020). It released USD 22.4 billion of Islamic securities during the first semester of 2018, a 9\% rise from the first semester of 2017 (IIFM Sukuk Report, 2019, 2020; Islamic Financial Services Board, 2020). This Islamic securities growth illustrates why Malaysia is the pioneering Islamic finance country with the best Global Islamic Economy Indicator (GIEI) ranking of 111, representing the best success of Islamic finance in the world (Reuters, 2020).

Similarly, Indonesia saw phenomenal growth in the Islamic finance sector and Islamic securities markets, close to the direction of Malaysian Islamic finance. In 2018, the Indonesian Islamic securities market saw steady growth facing a competitive environment. Relevant international challenges have resulted in sluggish global economic development impacting Indonesia's Islamic capital markets. Even so, at the launch of Islamic securities in 2018, both the Indonesian Government and the Islamic securities companies remained in a good position with continued expansion in the first semester of 2018; Islamic securities about USD 2,472 billion has been issued from both the Indonesian Government and the Islamic securities firms, a rise of 37.13\% from the first semester of 2017 (Islamic Financial Services Board, 2020). This Islamic securities growth reflects why Indonesia, with a GIEI score of 49 , ranked fifth in Islamic banking and finance ranking worldwide (Reuters, 2020).

Following the growth of the Islamic securities markets in Malaysia and Indonesia, Brunei Darussalam is an excellent underground destination for the Islamic finance business and the Islamic securities markets. With an increasing number of issuances focused primarily on funding infrastructure projects, Brunei Darussalam continues to dominate the international market in Islamic securities since the Brunei Government, through its delegate, Autoriti Monetari Brunei 
Darussalam (AMBD), published its 164th Islamic securities series valued at BND 50 million (IIFM Sukuk Report, 2019, 2020). Via this issuance, both the AMBD and the Islamic securities financial firms issued USD 1,730,380 million Islamic securities during the first semester of 2018, a rise of $19.32 \%$ from the first semester of 2017 based on the Islamic Financial Services Board (2020). This Islamic securities creation reflects why Brunei Darussalam positioned the 10th country with a GIEI score of 40 in Islamic finance best internationally achievement (Reuters, 2020).

Based on the study of Echchabi et al. (2018) and Yildirım et al. (2020), pure research that explores the nexus between Islamic securities and economic growth is minimal, so there is a lack of understanding of this relationship. Consequently, this research is enriching the literature by offering a purer analysis of this relationship from a solid sampling of Southeast Asia which contains developed Islamic capital markets.

Currently, Southeast Asia has seen a substantial increase in capital supplies, savings and the accumulation of expertise, which has led to rapid economic growth in the sense of "the endogenous growth model" (Canlas, 2020). For this purpose, based on the theoretical perspective of the "endogenous growth model" which is an expansion of the "Supply leading hypothesis" in Southeast Asia that contains the top Islamic securities issuers (Malaysia, Indonesia and Brunei Darussalam), this paper is exploring empirically the relationship between Islamic securities and economic growth. Therefore, this paper answers the ensuing question: "Do Islamic securities enhance economic growth in Southeast Asia?"

\section{Literature review}

\subsection{The theoretical framework of Islamic securities-economic growth nexus}

2.1.1 Islamic securities-economic growth nexus based on the supply-leading hypothesis. By focusing on the "Supply-leading hypothesis" of Schumpeter theorem (Schumpeter, 1934), the interpretation of McKinnon (1973) and Shaw (1973) is consistent with the principle of financial exploitation, which determines that finance enhances economic development, in which capital securities markets and financial channels of investments can increase economic growth. This hypothesis was widely tested and validated in many empirical studies (Hafnida and Abdullah, 2016). However, as stated by Adeyeye et al. (2015), the weakness of this hypothesis is that it cannot be always supported in the case of developing economies. On the other hand, relating to the contribution of Islamic securities capital markets to economic growth, various empirical studies like Tabash and Dhankar (2014), Mitsaliyandito et al. (2017) and AlFathan and Arundina (2019) support the supply-leading theory by demonstrating that Islamic securities (șukūk) markets enhance economic growth.

2.1.2 Islamic securities-economic growth nexus based on the demand-following hypothesis. The "demand-following hypothesis" was championed by Robinson (1952), who stated that financial progress follows economic growth which means that economic growth leads to financial progress. However, according to Odhiambo (2007), this hypothesis has not been widely supported in the literature where economic growth leads to financial progress. As well, to the best of the authors' knowledge, this hypothesis was not supported on the promotion of economic growth to the Islamic securities markets' development in the existing literature.

2.1.3 Islamic securities-economic growth nexus based on the mutual-dependence hypothesis. Patrick (1966) proposed the "mutual-dependence hypothesis"; this hypothesis states that the causality of financial development-economic growth is reciprocal (bi-directional relationship). According to Khalifa Al-Yousif (2002), although this hypothesis has been discussed in several empirical studies, it cannot be always supported across developing and developed economies due to the variances in financial development that are determined by economic policies and organizations. Additionally, concerning the Islamic securities-economic growth relationship, it was not widely validated based on a mutually causal relationship; only a few empirical studies like Muharam et al. (2019) and Sabiu and Abduh (2020) support this hypothesis. 
IES

29,2

122

2.1.4 Islamic securities-economic growth relationship based on the endogenous growth theory. As an extension of these classical concepts, the theory of endogenous growth by Paul Romer proposes that economic growth is influenced by exogenous variables such as financial markets beneath the model of economic growth of Romer (2011) due to investment progress and the rise of the human capital stock (Jhingan, 2011). Additionally, many notable empirical studies are corroborative that financial markets of securities are exogenous factors inside the model of endogenous growth. Bencivenga and Smith (1991) showed that financial intermediation enhanced loans that could fund long-term investments, owing to the increase in deposits and capital supplies, leading to economic growth depending on the endogenous growth model. Correspondingly, Saint-Paul (1992) showed that financial markets foster technical specialization in entrepreneurship that contributes to economic growth.

Besides, Blackburn and Hung (1998) decided that the development of the financial system and trade liberalization could stimulate the development of intermediation which stimulates economic growth. Similarly, Hassan et al. (2011) and Levine and Zervos (1998) have determined that finance development and capital markets of securities encouraged technological growth by growing innovation, which contributes to high productivity and is thus essential for economic growth depending on the endogenous growth model, these findings were confirmed also by the two notable studies of Rajan and Zingales (1996) and King and Levine (1993). Above and beyond, all of the noteworthy papers of Fanta and Makina (2017), Pradhan et al. (2015) and Thumrongvit et al. (2013) demonstrated that the securities financial markets have enhanced economic activity by stimulating expenditure and capital stocks. As a result, securities development boosts economic growth based on the endogenous growth theory.

Since Islamic securities are a category of securities in financial markets, many remarkable studies like Malikov (2017), Mitsaliyandito et al. (2017), Smaoui and Nechi (2017), Sari et al. (2018) and Ledhem (2020) have determined that Islamic securities development encourages economic growth through expanding investment and capital assets. Therefore, in the sense of the "endogenous growth theory", Islamic securities are an exogenous factor that positively impacts economic growth when investments and capital stocks are raised by Islamic securities financing. As well, Islamic finance is improving economic growth internationally as an exogenous driver according to the endogenous growth concept (Ledhem and Mekidiche, 2020, 2021). Consequently, because Islamic securities are part of Islamic finance that enhance endogenous economic growth, it is easier to infer that the factor of Islamic securities is an exogenous variable that promotes economic growth in the sense of endogenous growth theory.

\subsection{Earlier empirical studies}

Studies that found Islamic finance is enhancing economic growth are many like the study of Boukhatem and Moussa (2018) and Ledhem and Mekidiche (2020). However, only limited pure studies empirically investigate the relationship between Islamic securities and economic growth. Therefore, and to enrich studies on the Islamic securities and economic growth, this study explores the nexus between Islamic securities and economic growth based on the modelling of endogenous growth, and it examines empirically the effect of Islamic securities on economic growth as an exogenous factor inside the endogenous growth model based on a non-parametric approach. Thus, this study is the first that addresses the exploration of the Islamic securities-economic growth nexus in the outline of the endogenous growth theory. Consequently, it is believed that this paper will add a substantial contribution to the existing literature.

In a recent study, Ledhem (2020) investigated the link between the financing of Islamic securities (șukūk) and economic growth in all of Indonesia, Brunei Darussalam and Malaysia based on a quarterly sample from 2013Q4 till 2019Q3. Using panel system GMM, Ledhem (2020) examined the effect of Islamic securities on the gross domestic product (GDP) as the 
factor of economic growth. The findings indicated that Islamic securities had a positive Islamic securities impact on economic growth.

Similarly, via a sample of nine developed countries in Islamic finance over periods from 2014Q1 to 2017Q4, Yildirm et al. (2020) calculated the impact of Islamic securities market creation on economic growth. As an indicator of economic growth, they used panel co-integration regression with a dependent variable of the GDP. Total Islamic securities exports were used as a quantity for the Islamic securities market as independent variables, while Islamic securities density was used as a quantity for the growth of the Islamic securities market. Trade, inflation and financial stress were adopted as control variables. Their results indicated the presence of a long-term co-integration connection between the production of the Islamic securities sector and economic growth when the Islamic securities density and Islamic securities exports had a positive impact on economic growth.

Correspondingly, Al-Raeai et al. (2018) surveyed the effect of the macro-economic factors on the growth of the Islamic securities market in Gulf Cooperation Council (GCC) for the period 2001-2016 to introduce Islamic securities as an alternate source of financing. They concluded that economic growth could be enhanced by Islamic securities market development.

In the same context, Sari et al. (2018) evaluated the effect of Islamic securities in three outstanding Islamic capital markets on economic growth in Indonesia from January 2011 to December 2011. To evaluate the nature of a long-term relationship between the Islamic stock market of Islamic securities and economic growth, they used the co-integration regression. Their findings suggested that Islamic securities in the Islamic stock market are driving economic growth over the long term to be a substitute financial instrument in Indonesia.

In a similar study, Malikov (2017) discussed the effect of Islamic securities sovereigns on economic development in Saudi Arabia and Malaysia. Using statistical analysis, he tested the substantial effect of sovereign Islamic securities issuance on GDP which was a proxy for economic growth. Its findings found that the sovereign issuance of Islamic securities had a positive impact on economic development in Saudi Arabia and Malaysia.

Also, Mitsaliyandito et al. (2017) studied the effects of market developments of Islamic securities on Indonesian economic growth from 2009 to 2016. They employed VAR and Granger causality to evaluate the effect of Islamic securities market developments on economic growth. The remaining Islamic securities were used as an independent variable for the volume of the Islamic securities market, the GDP was used as the dependent variable. Their findings showed that Indonesia's economic growth was positively impacted by the Islamic securities domestic sovereign market.

Further, the effects of the financial market production of Islamic securities on economic growth were studied by Smaoui and Nechi (2017) using a sample of all Islamic securitiesexporting countries from 1995 until 2015. They used the GMM method for empirical analysis. Islamic securities market growth was driven by two variables, namely the Islamic securities market capitalization ratio and the overall issued Islamic securities. They stated that the expansion of the Islamic securities market has fuelled economic growth.

Then again, Khoutem (2014) investigated the association between Islamic banking and the Islamic securities markets on Tunisian economic growth after the Tunisian revolution of 2011. Their results have shown that Islamic intermediation has boosted the Islamic securities markets, which have been capable of improving economic development in Tunisia.

Supplementary to this, Echchabi et al. (2016) estimated the effect of Islamic securities issuance on economic growth in the main Islamic securities issuance countries from 2005 to 2012. Toda and Yamamoto's approach has been adopted to estimate the effect of Islamic securities as the primary independent variable, trading operations and gross capital creation as control variables on the GDP as the dependent variable for economic growth. They indicated that Islamic securities issuance has little impact on economic growth. 
IES

29,2

In different special cases, Echchabi et al. (2018) examined the effect of Islamic securities on economic growth among GCC countries from 2005 to 2012. They used GDP as the dependent variable for economic growth, Islamic securities issuance as the primary independent variable while trading operations, and gross capital investment as the control variables. They used the approach of Toda and Yamamoto. They indicated that the financing of Islamic securities did not affect economic development. Similar to this finding, Grassa and Gazdar (2014) and Ibrahim (2015) had determined that Islamic securities markets are not promoting economic growth.

Most of the previous studies have agreed that Islamic securities enhance economic growth in which the "supply-leading hypothesis" of Schumpeter (1934) is confirmed. Thus, the validity of the Schumpeter understanding concerning the promotion of Islamic securities on economic growth is confirmed in the most literature, except for the studies of Echchabi et al. (2018), Grassa and Gazdar (2014) and Ibrahim (2015) that found that Islamic securities do not enhance economic growth in which this conclusion is reliable with Lucas's (1988) "neutrality hypothesis", which is built on the concept that the finance is a useless factor to economic growth and not an imperative factor to the growth cycle.

However, as reported by Ledhem (2020) and Echchabi et al. (2018), pure research that explores the association between Islamic securities and economic growth is limited; so there is a lack of understanding of this relationship. Thus, this paper is enriching the literature by offering a purer examination of this relationship from a solid sampling of Southeast Asia which comprises extraordinary Islamic securities markets. Consequently, this research is enriching the literature on the Islamic securities-economic growth nexus by investigating it based on the "endogenous growth theory".

Concerning the empirical methodology, all of the previous studies have employed parametric approaches to investigate the nexus between Islamic securities and economic growth, in which panel regression methods like panel regression with fixed and random effects and panel GMM were used. Nevertheless, all the empirical investigations were parametric approaches and not non-parametric. As stated by Asmare and Begashaw (2018), Jureckova et al. (2012), Hettmansperger and McKean (2011) and Ullah (1989), non-parametric approaches produce better results for empirical investigations. For this reason, this paper is filling a literature gap of missing to employ the non-parametric approaches which can be more competent and accurate in the estimation results than the parametric approaches which assume that empirical model's errors follow certain parametric distributions (Ullah, 1989; Hettmansperger and McKean, 2011; Jureckova et al., 2012; Asmare and Begashaw, 2018). According to Dong et al. (2015), one of the efficient non-parametric methods for robust estimation is Markov chain Monte Carlo (MCMC) quantile regression. Therefore, since this method was not adopted in the previous studies for investigating the relationship between Islamic securities and economic growth, this study is adopting this method for getting accurate empirical findings, also, based on the literature, this study is adopting the most suitable variables for exploring the Islamic securities-economic growth nexus.

Consequently, this is the first study that investigates the Islamic securities-economic growth nexus using a non-parametric approach within a robust theoretical background of the "endogenous growth theory". Hence, it is believed that this paper will make a noteworthy contribution to the literature.

\section{Research methodology}

\subsection{Sample and assortment of data}

This study employs balanced panel data from all working Islamic financial institutions in the three main Islamic securities issuance countries of South-East Asia (Malaysia, Brunei Darussalam and Indonesia) spanning from the fourth quarter of 2013 to the fourth quarter of 
2019 (2013Q4-2019Q4). The Islamic securities data were extracted from the database of the Islamic Financial Services Board. The added macro-economic data were obtained from the Central Bank of Malaysia (Negara), the Indonesian Central Bank, the Ministry of Finance and Economy in Brunei Darussalam and the IMF database. Since all countries (Malaysia, Indonesia and Brunei Darussalam) have varied currencies, the entire quarter financial values are changed to the US dollar by proper average exchange rates from the International Monetary Fund (IMF) database.

\section{Islamic securities (sukūk) and economic growth}

\subsection{Experimental variables}

3.2.1 Islamic securities variable. Following Ledhem (2020), Y1ldırım et al. (2020), Echchabi et al. (2018) and Smaoui and Nechi (2017), this paper employs total issued Islamic securities holdings as a determinant for the Islamic securities variable (ISEC) in all of Malaysia, Indonesia and Brunei Darussalam (Table 1).

3.2.2 Economic growth factor. All the previous studies in this paper focused on employing the GDP as a measurement for economic growth when it is investigated with Islamic securities and Islamic financing. Thus, this paper employs the GDP as a dependent variable for economic growth (Malikov, 2017; Al-Raeai et al., 2018; Smaoui and Nechi, 2017; Echchabi et al., 2018; Yildırım et al., 2020; Ledhem, 2020) (Table 1).

3.2.3 Control variables. To demonstrate the possible impact of other economic growth determinants, several control variables are used in the estimated model to prevent the issue of bias due to the missed macroeconomic variables; these variables are used based on the literature on the association between Islamic securities and economic growth and also on the relationship between Islamic finance and economic growth. Thus, this study adopts trade openness index which signifies the external sector (TRADE) (Smaoui and Nechi, 2017; Boukhatem and Moussa, 2018; Al-Raeai et al., 2018; Yıldırım et al., 2020; Ledhem, 2020; Ledhem and Mekidiche, 2020), consumer price index (CPI) which measures inflation (Smaoui and Nechi, 2017; Kassim, 2016; Ledhem and Mekidiche, 2020; Yildırım et al., 2020; Ledhem, 2020 ) and gross fixed capital formation (GFCF) as a measurement for investments (Kassim, 2016; Ledhem, 2020; Ledhem and Mekidiche, 2020) (Table 1).

\subsection{Estimating model}

According to the literature, most empirical studies that investigate the association between Islamic securities and economic growth have adopted panel regression models such as panel regression (fixed effects and random effects) and panel GMM. However, all the empirical investigations were parametric approaches and not non-parametric. Although the parametric approaches produce better results and have significant advantages in modelling data that suffer from critical measurement errors as stated by Asmare and Begashaw (2018), it is not enough for robust estimation results, due to the possible misleading results in the parametric approaches, which can be generated from the assumption that errors in the empirical models follow certain parametric distributions (Ullah, 1989; Hettmansperger and McKean, 2011; Jureckova et al., 2012; Asmare and Begashaw, 2018). Thus, this paper is filling a gap of missing to employ robust non-parametric approaches that can offer better estimation results from investigating and exploring the relationship between Islamic securities and economic growth. Following the research of Powell (2014), this paper employed the panel quantile regression as a robust non-parametric approach to explore the impact of economic stimulus payments on labour supply. Moreover, by following the new approach of Powell (2017), this paper employed panel quantile regression with the optimization of MCMC as a new robust non-parametric approach. As well, employing the non-parametric method of panel quantile regression with MCMC optimization offers more exploration to the Islamic securitieseconomic growth nexus by measuring the effect of different quantiles of Islamic securities 
IES
29,2

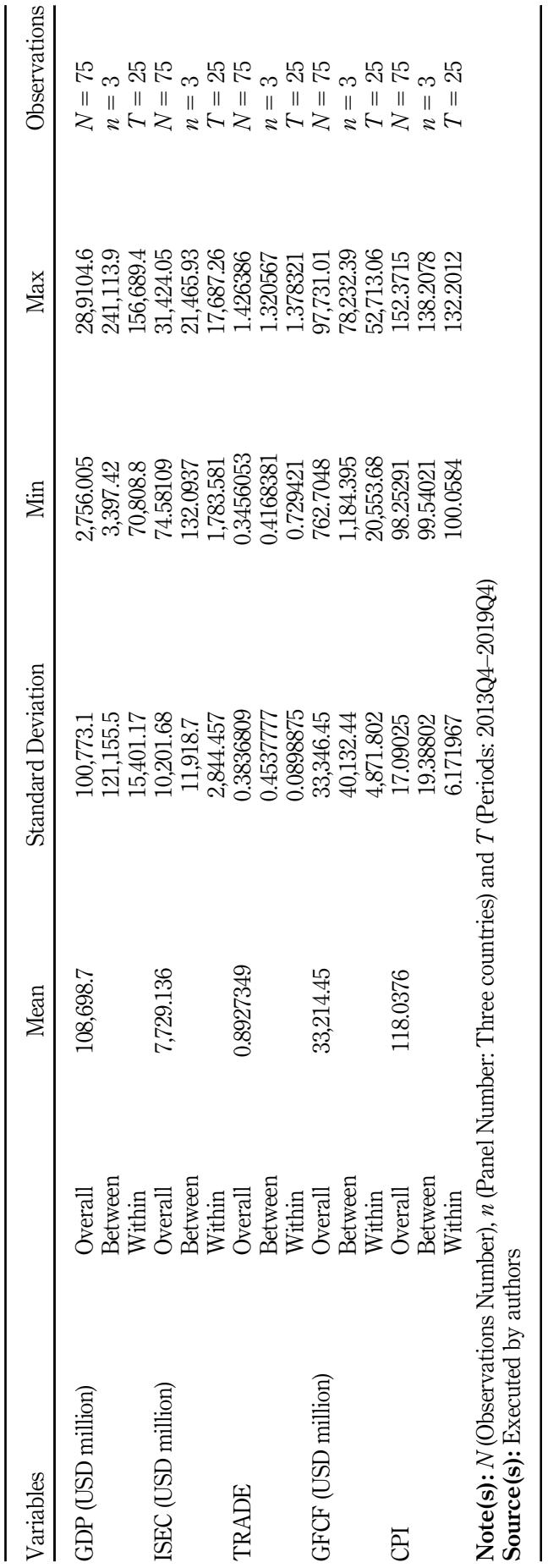

Table 1.

Descriptive statistics summary of the employed panel data

का

$z \approx A z \approx A Z \approx A Z \approx A Z \approx R$

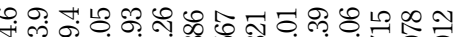

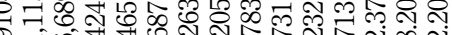

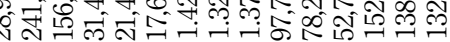

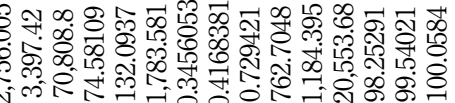

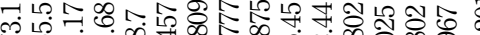

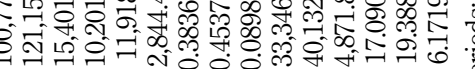

r 
on economic growth; this advantage in this non-parametric analysis cannot be provided by the parametric methods.

In the empirical analysis of economic growth, the elementary issue is the use of appropriate control variables within the model (Ledhem and Mekidiche, 2021). In the empirical modelling, Brock and Durlauf (2001) identified this issue of using the control variables as an "open-ended hypothesis" of the causal relationship between economic growth and another variable. This hypothesis stated that it was difficult to regulate the association between economic growth and another variable. That is exactly what the research of Durlauf and Quah (1999) have accomplished by presenting around 90 variables that can affect economic growth.

However, the principal purpose of this analysis is not to promote all hypotheses of economic growth through the financing of Islamic securities, but to investigate whether and how the financing of Islamic securities impacts economic growth in the light of endogenous growth theory. For this reason, the minimum model for estimating the financial effects of Islamic securities on economic growth has been quantified in this study. Thus, the possible macroeconomic factors (TRADE, GFCF and CPI) are used to erase the bias problem by following prior empirical studies associated with the subject. Consequently, following the path of the endogenous growth theory, the general model for investigating the Islamic securities-economic growth nexus is as follows (Figure 1):

$$
\mathrm{GDP}=\mathrm{ISEC}+\mathrm{TRADE}+\mathrm{GFCF}+\mathrm{CPI}
$$

where GDP is a dependent variable, ISEC is the independent variable and TRADE, CPI and $\mathrm{GFCF}$ are the control variables.

\subsection{Econometric methodology}

Based on the research of Powell (2014), quantile regression for the panel data (QRPD) is a nonparametric approach for panel data estimation particularly for small periods $T$ in the panel data; it is well defined as follows:

$$
Y_{i t}=D_{i t}^{\prime} \beta\left(U_{i t}^{*}\right), U_{i t}^{*} \sim U(0,1)
$$

where, for a given variable treatment set represented by $D_{i t}, D_{i t}^{\prime} \beta(\tau)$ denotes stringently increasing conditional distribution quantile $(\tau)$ and $Y_{i t}$ is the economic growth measure (GDP)

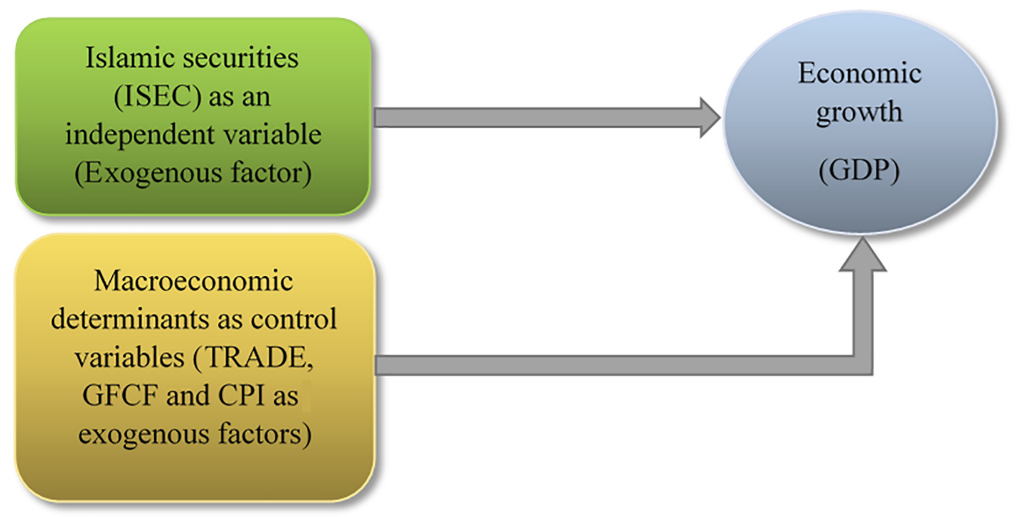

Source(s): Arranged by authors

Islamic securities (sukūk) and economic growth

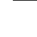


IES

29,2

128

for country $i$ at time $t . U_{i t}^{*}$ signifies the independent variable which is Islamic securities (ISEC) and the control variables (TRADE, GFCF and CPI), while $\beta$ signifies coefficients.

As stated in the research of Powell (2014), the quantile treatments (QTEs) characterize the alteration causal effect of the treatment variables from $d_{1}$ to $d_{1}$ on $Y_{i t}$, by holding $\tau$ fixed as the ensuing:

$$
d_{2}^{\prime} \beta(\tau)-d_{1}^{\prime} \beta(\tau)
$$

The estimator of QRPD which estimates the properties of QTEs for the outcome variable $Y_{i t}$ is determined by engaging a similar designation to Chernozhukov and Hansen (2008). Thus, this designation requires a structural quantile function (SQF) for Equation (2) as the subsequent:

$$
S_{Y}(T \mid d)=d^{\prime} \beta(\tau), \tau \in(0,1)
$$

The SQF states the quantile of the contained outcome variable $Y_{d}=d^{\prime} \beta\left(U^{*}\right)$ for a fixed $d$ and a randomly chosen $U^{*} \sim U(0,1)$. In other meaning, it designates the $\tau$ th conditional quantile of $Y$ for a given $d$ (Powell, 2014).

Then, the QRPD depends on the conditional restriction as shown by allowing $D_{i}=\left(D_{i 1}, \ldots, D_{i T}\right)$ :

$$
P\left(Y_{i t} \leq D_{i t}^{\prime} \beta(\tau) \mid D_{i t}\right)=\tau
$$

As reported by Powell (2014), this condition that states that the probability of the outcome variable is fewer than the quantile function is the same for all $D_{i t}$ and equal to $\tau$. The QRPD lets this probability vary through the individual and even within-individual on the condition that this variation is orthogonal to the instruments. Since the same individual can occur multiple times in panel data, this additional information can be employed to recognize that the probability of an individual has a small value of the outcome variable in which their treatment variables may not be $\tau$. Thus, instead, the QRPD depends on a conditional restriction and an unconditional restriction by allowing $D_{i}=\left(D_{i 1}, \ldots, D_{i T}\right)$ :

$$
\begin{gathered}
P\left(Y_{i t} \leq D_{i t}^{\prime} \beta(\tau) \mid D_{i t}\right)=P\left(Y_{i s} \leq D_{i s}^{\prime} \beta(\tau) \mid D_{i t}\right) \\
P\left(Y_{i t} \leq D_{i t}^{\prime} \beta(\tau)\right)=\tau
\end{gathered}
$$

In Equation (7), the QRPD estimator approves the probability to vary by individual and the estimator only uses within-individual assessments of this probability. Equation (7) approves that the probability of the outcome $Y$ is fewer than the quantile function which is equal to the $\tau$ th quantile, however, once more, the estimator approves for heterogeneity over individuals (Powell, 2014).

Finally, to estimate the conditional quantile function of the outcome $Y$, Koenker and Bassett (1978) and Koenker (2004) expressed the quantile regression with specified W under the deviation loss of asymmetric least absolute $\rho_{\tau}(u)=\left(\tau_{-1}(u<0)\right) u$, in which the $\tau$ th conditional quantile given $W$ is a problem solved as the following:

$$
Q_{Y}(\tau \mid w)=\operatorname{argmin}_{f \in \mathrm{F}} E\left[\rho_{\tau}(Y-f(W))\right]
$$

where $\mathbf{F}$ is the computable functions class of $W$, while $\tau=1 / 2, Q_{Y}(0.5 \mid w)$ is a median regression function of Laplace which is a resolution to the problem $\rho_{\tau}(u)=1 / 2|u|$ (Chernozhukov and Hansen, 2008).

Consequently, the estimated model using the quantile regression in this study is as follows:

$$
\mathrm{GDP}_{t}=\alpha_{\tau 1} \mathrm{ISEC}_{t}+\alpha_{\tau 2} \mathrm{TRADE}_{t}+\alpha_{\tau 3} \mathrm{GFCF}_{t}+\alpha_{\tau 4} \mathrm{CPI}_{t}, \tau \in(0,1)
$$


where $\alpha_{\tau 1}, \alpha_{\tau 2}, \alpha_{\tau 3}$ and $\alpha_{\tau 4}$ are coefficients, $\tau$ refers to the quantile, $t$ is the year quarter, GDP is a dependent variable, ISEC is the independent variable and TRADE, CPI and GFCF are the control variables.

Following Powell (2017), to get robust estimated results since the study sample is small (75 observations), this paper has performed the QRPD using MCMC optimization of Chernozhukov and Hong (2003), with an MCMC simulation process of 1,000 iteration performed to estimate the QRPD.

Islamic securities (sukūk) and economic growth

\section{Results and discussion}

To execute the quantile regression, this study employed the QPLOT command of Cox (2005) to choose the optimal quantile regression value. Using the QPLOT command of Cox (2005), this study illustrated the GDP, which appears reasonably symmetric at 0.5 quantiles as shown in Figure 2. Note that 0.5 quantiles are almost 100,000 which reflect an intermediate economic growth within Southeast Asia. Thus, the optimal regression is at 0.5 quantiles.

Choosing the 0.5 quantile regression value as the optimal value, Table 2 showed the estimated results of running panel quantile regression with MCMC optimization.

Table 2 displayed the estimation results of panel quantile regression with the optimization of 1,000 iterations within the MCMC method. The estimated results indicated that on the significance level of $1 \%$, the effect of Islamic securities issuance on economic growth is significantly positive ( $\phi$-value of ISEC: $0.000<0.01$ ), which confirms that Islamic securities enhance economic growth in Southeast Asia. If there is an increase of $1 \%$ in Islamic securities median value then the economic growth (GDP) will increase by $0.99 \%$ in the median value. Consequently, this result confirmed the validity of the hypothesis that economic growth is positively affected by Islamic securities in Southeast Asia based on the "endogenous growth theory". This finding is reliable with the "supply-leading hypothesis" of Schumpeter's thought (Schumpeter, 1934), in which financial development is a promoter of economic growth within Southeast Asia through Islamic securities.

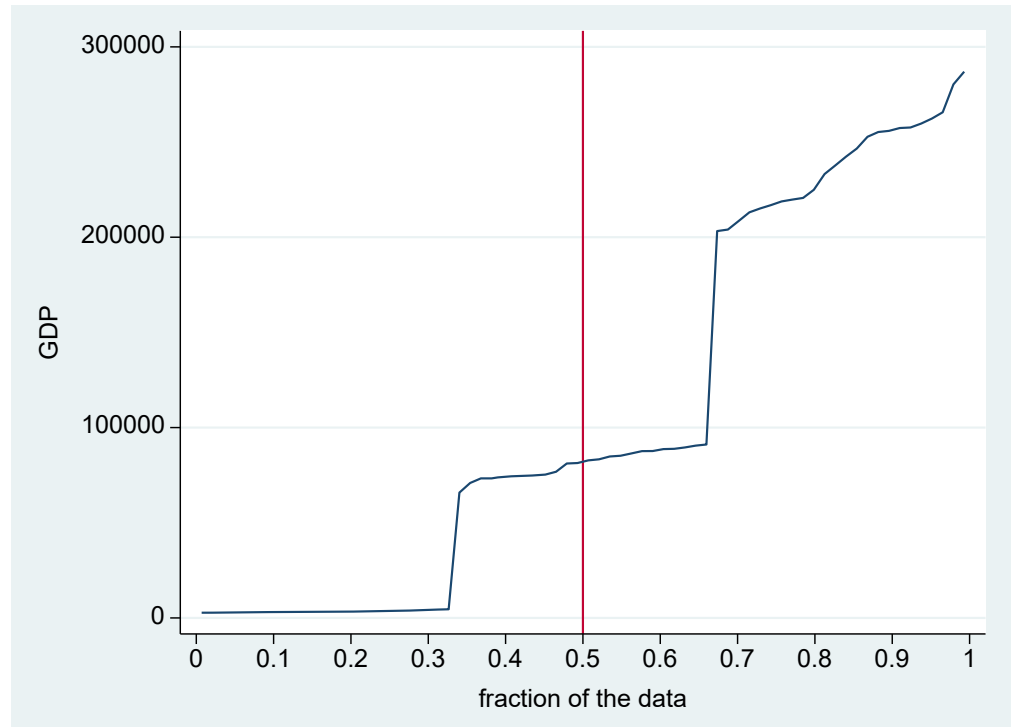

Source(s): Symmetric GDP fraction data over 0.5 quantiles

Figure 2.

Graph of the symmetric GDP fraction data over quantiles 
IES

29,2

130

Concerning other control variables' effect on economic growth, the proxy variable of investments (GFCF) is positively affecting the GDP at the significance level of $1 \%$ ( $\phi$-value of GFCF: $0.000<0.01$ ); therefore, investments promote Southeast Asia's economic growth; this result is consistent with the findings of Zhang (2001), who demonstrated that investments promoted economic growth of East Asian region, and with the findings of Hussin and Saidin (2012), who indicated that investments promoted economic growth in the Asian countries. The proxy factor of inflation (CPI) is statistically insignificant to the economic growth at a $5 \%$ significance level (CPI $p$-value: $0.1948>0.05$ ), that is consistent with the outcomes of Behera (2014) that determined that there is no association between inflation and economic growth in the majority of South Asian countries. The trade openness index is statistically insignificant and has no effect on economic growth at the $5 \%$ significance level ( $p$-value of TRADE: $0.1852>0.05$ ), which is reliable with the results of Ledhem and Mekidiche (2021) when they determined that trade openness has no impact on the economic growth of Southeast Asia.

For more detailed empirical investigation, the quantile process estimations are required; therefore, Table 3 provides estimations across $0.10,0.20,0.30,0.40,0.50,0.60,0.70,0.80$ and 0.90 quantiles. Lower quantiles (from quantile $=0.10$ to quantile $=0.30$ ) represent low-issued Islamic securities (ISEC) holdings on a low economic growth (economic recession), the medium quantiles (from quantile $=0.30$ to quantile $=0.70$ ) reflect intermediate-issued Islamic securities (ISEC) holdings on intermediate economic growth, while the upper quantiles (quantile $=0.70$ to quantile $=0.90$ ) represent high-issued Islamic securities (ISEC) holdings on high economic growth.

Table 3 reports only the 10 th quantile (0.10 quantile) which characterizes the lowest quantile of the total issued Islamic securities holdings; the Islamic securities (ISEC) do not affect economic growth. This outcome confirms that low-issued Islamic securities are not enough to make a significant contribution to the economic growth. This outcome is reliable with the finding of Echchabi et al. (2018) in which the low financing of issued Islamic securities does not promote economic growth. Whereas starting from the 20th quantile $(0.20$ quantile) to 90 th quantile (0.9 quantile) (low, intermediate and high quantiles), the economic growth (GDP) was increased due to the Islamic securities (ISEC) from 1.08\% to $1.10 \%$; these increase in the Islamic securities (ISEC) is causing a significant increase in the economic growth (Figure 3). Consequently, the increasing of issuing Islamic securities (șukuk) in Southeast Asia is increasing the contribution on economic growth. This successful contribution is referred to the success of the stimulating programs for Southeast Asian Islamic capital markets in Malaysia, Indonesia and Brunei Darussalam. The first successful program of stimulating the Islamic securities markets was in Malaysia when it released USD 22.4 billion of Islamic securities during the first semester of 2018, a 9\% rise from the first semester of 2017 (IIFM Sukuk Report, 2019, 2020; Islamic Financial Services Board, 2020). The second successful program of stimulating the Islamic securities markets was in

\begin{tabular}{|c|c|c|c|c|}
\hline \multicolumn{2}{|c|}{$\begin{array}{l}\text { Method: MCMC panel quantile } \\
\text { regression } \\
\text { Number of observations: } 75\end{array}$} & \multicolumn{3}{|c|}{$\begin{array}{l}\text { Optimal quantile regression: } 0.5 \\
\text { Total iterations: } 1,000\end{array}$} \\
\hline Variables & Coefficients & Standard Error & $t$ & $p>|t|$ \\
\hline ISEC & 0.996739 & 0.087314 & 11.41560 & $0.0000^{* * *}$ \\
\hline TRADE & -4329.600 & 3236.333 & -1.337810 & 0.1852 \\
\hline GFCF & 3.040288 & 0.043819 & 69.38244 & $0.0000^{* * *}$ \\
\hline CPI & 39.68110 & 30.31754 & 1.308849 & 0.1948 \\
\hline
\end{tabular}

Table 2.

Panel quantile regression with MCMC optimization outputs
Source(s): MCMC panel quantile regression executed by authors 


\begin{tabular}{|c|c|c|c|c|c|c|}
\hline Variables & Quantiles & Coefficient & Standard error & $t$ & $p>|t|$ & Islamic securities \\
\hline \multirow[t]{9}{*}{ ISEC } & 0.1 & 1.050474 & 0.739214 & 1.421069 & 0.1597 & economic \\
\hline & 0.2 & 1.089739 & 0.156504 & 6.963020 & $0.0000 * *$ & \\
\hline & 0.3 & 1.048522 & 0.155673 & 6.735394 & $0.0000^{* *}$ & \\
\hline & 0.4 & 1.056417 & 0.106498 & 9.919617 & $0.0000^{* * *}$ & \\
\hline & 0.5 & 0.996739 & 0.087357 & 11.40989 & $0.0000 * *$ & \\
\hline & 0.6 & 1.007991 & 0.067833 & 14.85995 & $0.0000 * *$ & 131 \\
\hline & 0.7 & 0.997909 & 0.072976 & 13.67442 & $0.0000^{* * *}$ & \\
\hline & 0.8 & 1.053342 & 0.086717 & 12.14686 & $0.0000 * *$ & \\
\hline & 0.9 & 1.108640 & 0.066765 & 16.60514 & $0.0000^{* * *}$ & \\
\hline \multirow{9}{*}{ TRADE } & 0.1 & -6758.722 & 2836.424 & -2.382832 & 0.0199 & \\
\hline & 0.2 & -9240.466 & 6341.780 & -1.457078 & 0.1495 & \\
\hline & 0.3 & -7086.023 & 6731.564 & -1.052656 & 0.2961 & \\
\hline & 0.4 & -6630.625 & 4345.519 & -1.525853 & 0.1315 & \\
\hline & 0.5 & -4329.600 & 3237.952 & -1.337141 & 0.1854 & \\
\hline & 0.6 & -4344.664 & 2276.207 & -1.908730 & 0.0603 & \\
\hline & 0.7 & -1464.142 & 2359.800 & -0.620451 & 0.5369 & \\
\hline & 0.8 & -1568.121 & 3528.949 & -0.444359 & 0.6581 & \\
\hline & 0.9 & -2028.571 & 3081.011 & -0.658411 & 0.5124 & \\
\hline \multirow[t]{9}{*}{$\mathrm{GFCF}$} & 0.1 & 2.878454 & 0.034565 & 83.27766 & $0.0000 * *$ & \\
\hline & 0.2 & 2.852222 & 0.089296 & 31.94117 & $0.0000^{* * *}$ & \\
\hline & 0.3 & 2.971538 & 0.098601 & 30.13705 & $0.0000^{* *}$ & \\
\hline & 0.4 & 2.997998 & 0.059164 & 50.67235 & $0.0000^{* * *}$ & \\
\hline & 0.5 & 3.040288 & 0.043841 & 69.34774 & $0.0000^{* *}$ & \\
\hline & 0.6 & 3.045937 & 0.031556 & 96.52368 & $0.0000^{* *}$ & \\
\hline & 0.7 & 3.094063 & 0.032800 & 94.33018 & $0.0000^{* * *}$ & \\
\hline & 0.8 & 3.099148 & 0.051739 & 59.89957 & $0.0000^{* *}$ & \\
\hline & 0.9 & 3.135765 & 0.052447 & 59.78898 & $0.0000 * *$ & \\
\hline \multirow[t]{9}{*}{ CPI } & 0.1 & 45.23664 & 25.49956 & 1.774016 & 0.0803 & \\
\hline & 0.2 & 76.02214 & 60.41021 & 1.258432 & 0.2124 & \\
\hline & 0.3 & 57.18734 & 62.07722 & 0.921229 & 0.3601 & \\
\hline & 0.4 & 58.38752 & 40.36262 & 1.446574 & 0.1524 & \\
\hline & 0.5 & 39.68110 & 30.33271 & 1.308195 & 0.1950 & \\
\hline & 0.6 & 40.23376 & 21.69690 & 1.854355 & 0.0678 & \\
\hline & 0.7 & 15.60388 & 23.00405 & 0.678310 & 0.4998 & \\
\hline & 0.8 & 16.94113 & 37.69976 & 0.449370 & 0.6545 & \\
\hline & 0.9 & 22.99470 & 35.98042 & 0.639089 & 0.5248 & \\
\hline \multicolumn{6}{|c|}{$\begin{array}{l}\text { Note(s): **Significant at } 1 \% \text { level } \\
\text { Source(s): Executed by authors }\end{array}$} & $\begin{array}{l}\text { MCMC panel quantile } \\
\text { process estimates }\end{array}$ \\
\hline
\end{tabular}

Indonesia where Islamic securities have been issued worth USD 2,472 billion from both the Indonesian government and the Islamic securities firms, a rise of $37.13 \%$ from the first semester of 2017 (Islamic Financial Services Board, 2020). The third successful program of stimulating the Islamic securities markets was in Brunei Darussalam when the AMBD published its 164th Islamic securities series valued at BND 50 million (IIFM Sukuk Report, 2019, 2020). Via this issuance, both the AMBD and the Islamic securities financial firms issued USD 1,730,380 million Islamic securities during the first semester of 2018, a rise of $19.32 \%$ from the first semester of 2017 based on the Islamic Financial Services Board (2020). Consequently, the Islamic capital market development in Southeast Asia is promoting economic growth. This finding is confirming the theoretical path of the "supply-leading hypothesis" of Schumpeter (1934) and the interpretation of McKinnon (1973) and Shaw (1973) which determines that finance development, capital securities markets development and financial channels of investments enhance economic growth. 
IES

29,2

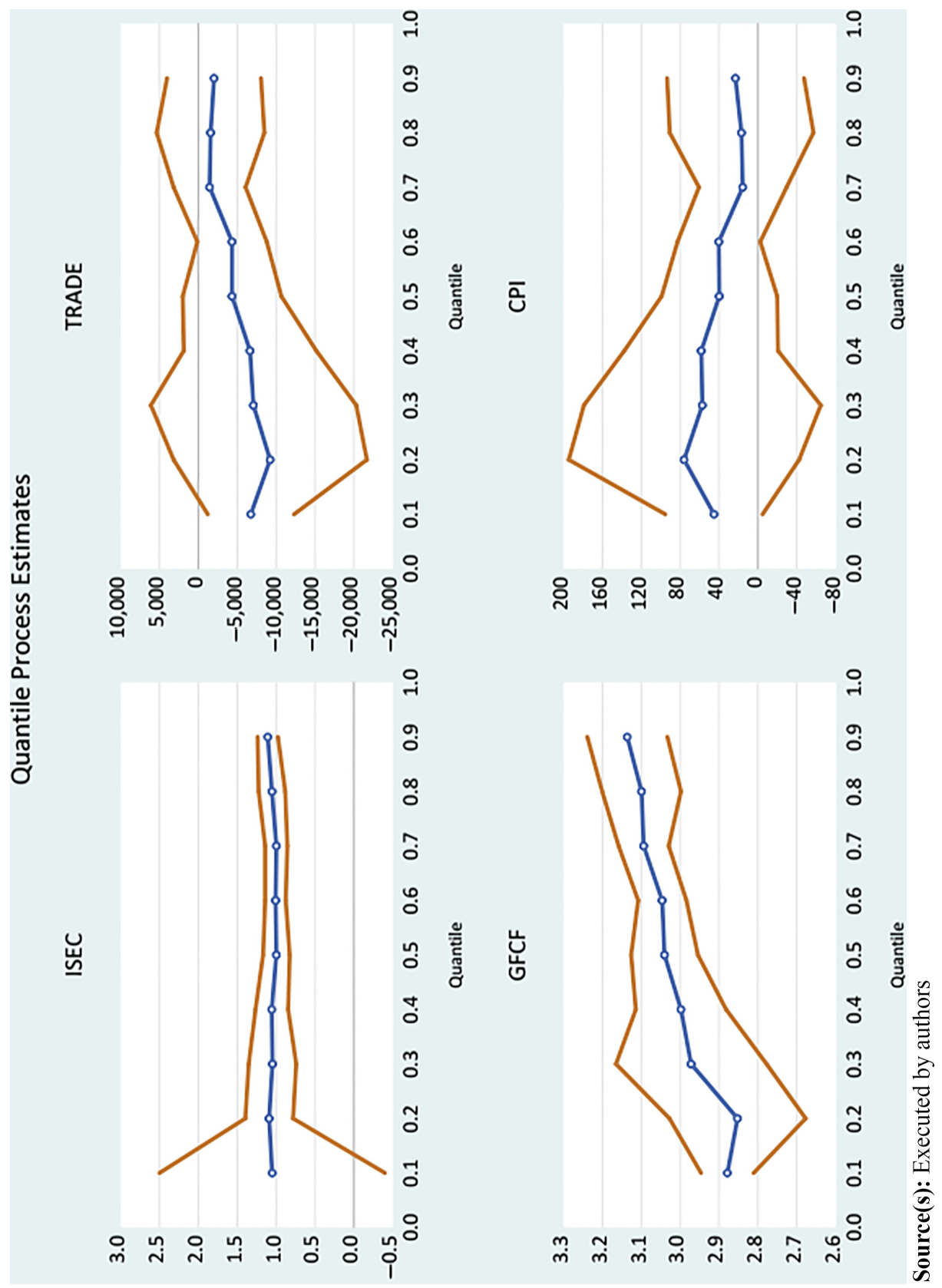

Figure 3.
Graphs of the MCMC

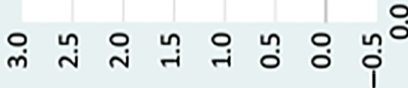

m 
Concerning other control variables, the trade openness index (TRADE) has no significant effect on the economic growth of Southeast Asia across all the quantiles. Regarding the GFCF, Table 3 reported that starting from the 10th quantile (0.10 quantile) to the 90 th quantile ( 0.90 quantile), the economic growth (GDP) increased due to the GFCF from $2.87 \%$ to $3.13 \%$ (Figure 3). Concerning the CPI, it has no significant effect on the economic growth of Southeast Asia across the quantiles.

Regarding the estimated model diagnostics, MCMC panel quantile regression requires testing the symmetric quantile test of Newey and Powell (1987) and the stability reset test of Ramsey (1969) (Table 4).

Based on the used Wald test in the test of Newey and Powell (1987), the chi-square value of the symmetric quantile test is not significant on the $5 \%$ level ( $p$-value: $0.4302>0.05$ ) (Table 4 ). There is evidence of symmetry over quantiles; therefore, the estimated MCMC panel quantile regression is not asymmetric.

Table 4 informs that the null hypothesis in the stability reset test of Ramsey (1969) cannot be rejected owing to the high insignificant $p$-value on the level of $5 \%$ ( $\phi$-value: $0.3512>0.05$ ). Thus, there is no evidence of the misspecification in the estimated model, for this reason, the estimated model is robustly stable against the misspecification from omitted variables, heteroskedasticity and autocorrelation issues.

By executing the diagnostic tests of symmetric quantile test of Newey and Powell (1987) and the stability test of Ramsey (1969), this paper proves that the estimated outcomes are truthful and robust to answer the research question of whether Islamic securities enhance economic growth in South-East Asia.

\section{Conclusion}

The main purpose of this paper is to determine empirically whether Islamic securities enhance the economic growth of Southeast Asia using the non-parametric analysis in the light of the theoretical background of endogenous growth. The findings show that Islamic securities had a positive impact on the economic growth of Southeast Asia. Dissimilar to the studies of Echchabi et al. (2018), Grassa and Gazdar (2014) and Ibrahim (2015), - that determined that Islamic securities do not stimulate economic growth in which those studies are reliable to "neutrality hypothesis" of Lucas's (1988), which claimed that finance is an impractical factor to economic growth - the empirical findings in this paper demonstrate that Islamic securities are promoting economic growth exogenously based on the "endogenous growth theory" (Romer, 2011), as well, since the increasing Islamic securities in Southeast Asia is leading to increased economic growth and the Islamic capital market development in

Test of symmetric quantile

Null hypothesis: There is no asymmetry in panel data

Wald test

Prob

16.33011

0.4302

Stability Ramsey reset test

Null hypothesis: No misspecification in the model

QLR $L$-statistic

Prob

0.869260

0.3512

Source(s): Executed by authors

Table 4.

Panel quantile regression diagnostics 
IES

29,2

Southeast Asia is promoting economic growth which validates the concept of the "supplyleading hypothesis" of Schumpeter (1934) and the interpretation of McKinnon (1973) and Shaw (1973) which claims that capital securities markets' development promote the economic growth. Therefore, this study is reliable with Ledhem (2020), Yildirim et al. (2020) and Al-Raeai et al. (2018) which showed that Islamic securities markets development is enhancing economic growth.

In this paper, the contribution of applying panel quantile regression with $\mathrm{MCMC}$ optimization to the body of knowledge in terms of sukūk market industry is to investigate whether the increase of issuing Islamic securities (sukūk) is increasing economic growth; this knowledge is achieved by exploring the effect of various quantiles of the total issued Islamic securities separately, and this advantage is not provided by other parametric methods that cannot measure the effect of increasing the issuance of Islamic securities over any economic variable such as economic growth. As a result, this study proves that Islamic securities are statistically significant and positive to the economic growth of Southeast Asia all over 0.20, $0.30,0.40,0.50,0.60,0.70,0.80$ and 0.90 quantiles, which approves that the increase of issuing Islamic securities in Islamic capital markets of Southeast Asia is increasing the levels of economic growth, reflecting the substantial role of the Islamic financial markets development as an imperative contributor to economic growth due to the successful stimulating programs for Southeast Asian Islamic capital markets in Malaysia, Indonesia and Brunei Darussalam. In addition, this paper fills a literature gap of missing to employ the non-parametric approaches in investigating the relationship between Islamic securities and economic growth. Thus, unlike previous studies, to gain robust estimated results, this paper is the first that applied a non-parametric analysis for a better understanding of how Islamic securities affect economic growth.

Above and beyond, this paper is extending previous literature by incorporating extra investigation for better understanding whether Islamic securities is enhancing economic growth within Southeast Asia, in which a new econometric investigation was employed using a powerful sample of the top Islamic securities (sukūk) issuance countries in Southeast Asia (Malaysia, Indonesia and Brunei Darussalam). Consequently, as an answer to the key question of this paper, Islamic securities enhance economic growth in Southeast Asia.

In conclusion, the Islamic finance industry is acting as a vital player in improving global economies, because developed and developing Muslim and non-Muslim countries have recently begun collaborating with Islamic securities, as one of the simplest ways to fund beyond the mainstream finance system (Yildırım et al., 2020). Furthermore, as reported by Azmat et al. (2021), Islamic securities can depend on customers' emphasis on religiosity; this makes Islamic securities as attractive instruments for investors as other conventional assets which indicates that Islamic securities can replace conventional assets in the capital markets from this side also. Consequently, although Islamic capital markets are still small compared to the conventional capital markets (IIFMSukuk Report, 2019, 2020), this paper indicates that Islamic capital markets are expected to be prosperous in the future as an alternative financial system that enriches economic growth through increasing the capital stock and investments, consistently with the expectations of Cevik and Bugan (2018), Ledhem (2020) and Yildirım et al. (2020).

\subsection{Research and practice implications}

Like the following, this study has some research and practice implications:

(1) This study aims to explore empirically whether Islamic securities enhance economic growth in Southeast Asia using the endogenous growth theory. Thus, the empirical investigation in this paper is expanding literature on the Islamic securities-economic 
growth nexus with the accurate theoretical context in Southeast Asia. Consequently, this paper serves as a roadmap for financial analysts, policymakers and decision makers to boost the Islamic securities market internationally as an alternate source of finance for maximum involvement in economic growth.

Islamic securities (șukūk) and economic growth

(2) In light of practical implications, this study provides valuable proof to financial analysts, business leaders, policymakers and related authorities that Islamic securities enhance economic growth, drawing global attention to the significant role of Islamic securities as an essential instrument of Islamic finance in approving the economic growth of Southeast Asia. As a result, financial analysts, policymakers and decision makers across countries are motivated by the need to stimulate and integrate Islamic securities into financial markets as an important player alongside conventional securities to fund investments that enhance economic development, particularly in Muslim countries which consist of a remarkable Islamic population.

\subsection{Limitations and future research}

To investigate the impact of Islamic securities on economic growth, this paper restricts the empirical investigation to the Southeast Asian region. Future research could consider expanding the sample by including the Middle East and North Africa countries since this region contains one of the top global Islamic securities markets, which is Saudi Arabia, as the second-largest șukūk issuer (IIFM Sukuk Report, 2019, 2020).

\section{References}

Adeyeye, P.O., Fapetu, O., Aluko, O.A. and Migiro, S.O. (2015), "Does supply-leading hypothesis hold in a developing economy? A Nigerian focus", Procedia Economics and Finance, Elsevier, Vol. 30, pp. 30-37.

Al Fathan, R. and Arundina, T. (2019), "Finance-growth nexus: Islamic finance development in Indonesia", International Journal of Islamic and Middle Eastern Finance and Management, Emerald Publishing, Vol. 12 No. 5, pp. 698-711.

Al-Ali, S. (2019), Raising Capital on Sukuk Markets: Structural, Legal and Regulatory Issues, 1st ed., Springer International Publishing; Palgrave Macmillan, (accessed 13 July 2020).

Al-Raeai, A.M., Zainol, Z., Rahim, A.K., bin, A. and Khilmy, A. (2018), "The role of macroeconomic factors on Sukuk market development of gulf cooperation council (gcc) countries", International Journal of Economics and Financial Issues, EconJournals, Vol. 8 No. 3, pp. 333-339.

Asmare, E. and Begashaw, A. (2018), "Review on parametric and nonparametric methods of efficiency analysis", Biostatistics and Bioinformatics, Vol. 2 No. 2, pp. 1-7.

Azmat, S., Kabir Hassan, M., Ali, H. and Sohel Azad, A.S.M. (2021), "Religiosity, neglected risk and asset returns: theory and evidence from Islamic finance industry", Journal of International Financial Markets, Institutions and Money, Vol. 74, p. 101294.

Behera, J. (2014), "Inflation and its impact on economic growth: evidence from six South Asian countries", Journal of Economics and Sustainable Development, Vol. 5 No. 7, pp. 145-154.

Bencivenga, V.R. and Smith, B.D. (1991), "Financial intermediation and endogenous growth", The Review of Economic Studies, Vol. 58 No. 2, pp. 195-209.

Blackburn, K. and Hung, V.T.Y. (1998), "A theory of growth, financial development and trade", Economica, Vol. 65 No. 257, pp. 107-124.

Boukhatem, J. and Moussa, F.B. (2018), "The effect of Islamic banks on GDP growth: some evidence from selected MENA countries", Borsa Istanbul Review, Vol. 18 No. 3, pp. 231-247.

Brock, W.A. and Durlauf, S.N. (2001), "What have we learned from a decade of empirical research on growth? Growth empirics and reality", The World Bank Economic Review, Vol. 15 No. 2, pp. 229-272. 
IES

29,2

Canlas, D.B. (2020), “(DP 2020-09) is there economic convergence in Asia?”, UPSE Discussion Papers, available at: https://econ.upd.edu.ph/dp/index.php/dp/article/view/1532 (accessed 28 August 2020).

Cevik, E.I. and Bugan, M.F. (2018), "Regime-dependent relation between Islamic and conventional financial markets”, Borsa Istanbul Review, Vol. 18 No. 2, pp. 114-121.

Chernozhukov, V. and Hansen, C. (2008), "Instrumental variable quantile regression: a robust inference approach”, Journal of Econometrics, Vol. 142 No. 1, pp. 379-398.

Chernozhukov, V. and Hong, H. (2003), “An MCMC approach to classical estimation”, Journal of Econometrics, Vol. 115 No. 2, pp. 293-346.

Cox, N.J. (2005), "Speaking stata: the protean quantile plot", The Stata Journal: Promoting Communications on Statistics and Stata, Vol. 5 No. 3, pp. 442-460.

Dong, A.X.D., Chan, J.S.K. and Peters, G.W. (2015), "Risk margin quantile function via parametric and NON-parametric Bayesian approaches", ASTIN Bulletin: The Journal of the IAA, Cambridge University Press, Vol. 45 No. 3, pp. 503-550.

Durlauf, S.N. and Quah, D.T. (1999), "The new empirics of economic growth", Handbook of Macroeconomics, Vol. 1, pp. 235-308.

Echchabi, A., Aziz, H.A. and Idriss, U. (2016), "Does Sukuk financing promote economic growth? An emphasis on the major issuing countries", Turkish Journal of Islamic Economics, Vol. 3 No. 2, pp. 63-73.

Echchabi, A., Aziz, H.A. and Idriss, U. (2018), "The impact of Sukuk financing on economic growth: the case of GCC countries", International Journal of Financial Services Management, Inderscience Publishers, Vol. 9 No. 1, pp. 60-69.

Fanta, A.B. and Makina, D. (2017), "Equity, bonds, institutional debt and economic growth: evidence from South Africa", South African Journal of Economics, Vol. 85 No. 1, pp. 86-97.

Grassa, R. and Gazdar, K. (2014), "Financial development and economic growth in GCC countries: a comparative study between Islamic and conventional finance", International Journal of Social Economics, Emerald Group Publishing, Vol. 41 No. 6, pp. 493-514.

Hafnida, S.M. and Abdullah, H. (2016), "Financial development and economic growth: an empirical investigation on 4 OIC countries", International Journal of Social Science and Economic Research, Vol. 1 No. 9, pp. 1400-1410.

Haini, H. (2019), "Examining the relationship between finance, institutions and economic growth: evidence from the ASEAN economies", Economic Change and Restructuring, Vol. 53 No. 4, pp. 519-542, doi: 10.1007/s10644-019-09257-5.

Hassan, M.K., Sanchez, B. and Yu, J.S. (2011), "Financial development and economic growth: new evidence from panel data", The Quarterly Review of Economics and Finance, Vol. 51 No. 1, pp. 88-104.

Hettmansperger, T.P. and McKean, J.W. (2011), Robust Nonparametric Statistical Methods, 2nd ed., CRC Press (accessed 26 September 2021).

Hussin, F. and Saidin, N. (2012), "Economic growth in ASEAN-4 countries: a panel data analysis", International Journal of Economics and Finance, Vol. 4 No. 9, pp. 119-129.

Ibrahim, M.H. (2015), "Issues in Islamic banking and finance: Islamic banks, Shari'ah-compliant investment and Sukuk", Pacific-Basin Finance Journal, Vol. 34, pp. 185-191.

IIFM Sukuk Report 2019 (2020), "International Islamic financial market", available at: https://www. iifm.net/sukuk-reports/ (accessed 14 July 2020).

Islamic Financial Services Board, (IFSB) (2020), "Islamic financial Services board (IFSB)", available at: https://www.ifsb.org/psifi_06.php (accessed 11 February 2020).

Jhingan, M.L. (2011), The Economics of Development and Planning, Vrinda Publications, Delhi.

Jureckova, J., Sen, P., Picek, J., Sen, P. and Picek, J. (2012), Methodology in Robust and Nonparametric Statistics, CRC Press, Boca Raton, FL, doi: 10.1201/b12681. 
Kassim, S. (2016), "Islamic finance and economic growth: the Malaysian experience", Global Finance Journal, Vol. 30, pp. 66-76.

Khalifa Al-Yousif, Y. (2002), "Financial development and economic growth: another look at the evidence from developing countries", Review of Financial Economics, Vol. 11 No. 2, pp. 131-150.

Islamic securities (sukūk) and economic growth

Khoutem, D.B.J. (2014), "Islamic banks-Sukuk markets relationships and economic development: the case of the Tunisian post-revolution economy", Journal of Islamic Accounting and Business Research, Vol. 5 No. 1, pp. 47-60.

King, R.G. and Levine, R. (1993), "Finance and growth: Schumpeter might be right", The Quarterly Journal of Economics, Vol. 108 No. 3, pp. 717-737.

Koenker, R. (2004), "Quantile regression for longitudinal data", Journal of Multivariate Analysis, Academic Press, Vol. 91 No. 1, pp. 74-89.

Koenker, R. and Bassett, G. (1978), "Regression quantiles", Econometrica, Vol. 46 No. 1, pp. 33-50.

Lahsasna, A., Hassan, M.K. and Ahmad, R. (2018), Forward Lease Sukuk in Islamic Capital Markets: Structure and Governing Rules, 1st ed., Springer International Publishing; Palgrave Macmillan, (accessed 3 April 2020).

Ledhem, M.A. (2020), "Does Sukuk financing boost economic growth? Empirical evidence from Southeast Asia”, PSU Research Review. doi: 10.1108/PRR-09-2020-0028.

Ledhem, M.A. and Mekidiche, M. (2020), "Economic growth and financial performance of Islamic banks: a CAMELS approach", Islamic Economic Studies, Emerald Publishing, Vol. 28 No. 1, pp. 47-62.

Ledhem, M.A. and Mekidiche, M. (2021), "Islamic finance and economic growth nexus: an empirical evidence from Southeast Asia using dynamic panel one-step system GMM analysis", Journal of Islamic Accounting and Business Research, Vol. 12 No. 8, pp. 1165-1180, doi: 10.1108/JIABR-032021-0107.

Levine, R. and Zervos, S. (1998), "Stock markets, banks, and economic growth", American Economic Review, pp. 537-558.

Lucas, R.E. Jr (1988), "On the mechanics of economic development”, Journal of Monetary Economics, Vol. 22 No. 1, pp. 3-42.

Malikov, A. (2017), "How do sovereign Sukuk impact on the economic growth of developing countries? An analysis of the infrastructure sector", in Efendić, V., Hadžić, F. and Izhar, H. (Eds), Critical Issues and Challenges in Islamic Economics and Finance Development, Springer International Publishing, Cham, pp. 1-37.

McKinnon, R.I. (1973), Money and Capital in Economic Development, Brookings Institution Press, Washington, DC.

Mitsaliyandito, R.Q., Arundina, T. and Kasri, R.A. (2017), "Impact of Sukuk market development on Indonesian Economic growth", International Journal of Applied Business and Economic Research, Serials Publications, Vol. 15 No. 24, pp. 537-549.

Muharam, H., Anwar, R.J. and Robiyanto, R. (2019), "Islamic stock market and Sukuk market development, economic growth, and trade openness (the case of Indonesia and Malaysia)", Business: Theory and Practice, Vilnius Gediminas Technical University, Vol. 20 No. 1, pp. 196-207.

Newey, W.K. and Powell, J.L. (1987), "Asymmetric least squares estimation and testing", Econometrica, [Wiley, Econometric Society], Vol. 55 No. 4, pp. 819-847.

Odhiambo, N.M. (2007), "Supply-leading versus demand-following hypothesis: empirical evidence from three SSA countries", African Development Review, Wiley Online Library, Vol. 19 No. 2, pp. 257-280.

Patrick, H.T. (1966), "Financial development and economic growth in underdeveloped countries", Economic Development and Cultural Change, Vol. 14 No. 2, pp. 174-189.

Powell, D. (2014), "Did the economic stimulus payments of 2008 reduce labor supply?: evidence from quantile panel data estimation", RAND Corporation, available at: https://www.rand.org/pubs/ working_papers/WR710-3.html (accessed 4 September 2020). 
IES

29,2

Powell, D. (2017), "Quantile treatment effects in the presence of covariates", available at: https://works. bepress.com/david_powell/4/ (accessed 27 February 2020).

Pradhan, R.P., Zaki, D.B., Maradana, R.P., Dash, S., Jayakumar, M. and Chatterjee, D. (2015), "Bond market development and economic growth: the G-20 experience", Tékhne, Vol. 13 No. 1, pp. 51-65.

Rajan, R.G. and Zingales, L. (1996), Financial Dependence and Growth, National Bureau of Economic Research, Cambridge, MA.

Ramsey, J.B. (1969), "Tests for specification errors in classical linear least-squares regression analysis", Journal of the Royal Statistical Society: Series B (Methodological), Vol. 31 No. 2, pp. 350-371.

Reuters, T. (2020), State of the Global Islamic Economy Report 2019/20, Thomson Reuters, DinarStandard, available at: https://www.salaamgateway.com/SGIE19-20 (accessed 3 January 2020).

Robinson, J. (1952), "The generalisation of the general theory”, The Rate of Interest, and Other Essays, 2nd ed., Palgrave MacMillan, London.

Romer, D. (2011), "Endogenous growth", Advanced Macroeconomics, 4th ed., McGraw-Hill, New York, pp. 101-149.

Sabiu, T.T. and Abduh, M. (2020), "Islamic financial development and economic growth in Nigeria: a bounds testing approach", Journal of Islamic Monetary Economics and Finance, Vol. 6 No. 3, pp. 597-620.

Saint-Paul, G. (1992), "Technological choice, financial markets and economic development”, European Economic Review, Vol. 36 No. 4, pp. 763-781.

Sari, N., AK, S. and Widiyanti, M. (2018), "The impact of Islamic capital market development on economic growth: the case of Indonesia”, Journal of Smart Economic Growth, Vol. 3 No. 2, pp. 21-30.

Schumpeter, J. (1934), Theorie der Wirtschaftlichen Entwicklung (English Edition), The Theory of Economic Development, Harvard University Press, Cambridge, MA.

Shaw, E.S. (1973), Financial Deepening in Economic Development, Oxford University Press, New York, NY.

Smaoui, H. and Nechi, S. (2017), "Does Sukuk market development spur economic growth?", Research in International Business and Finance, Vol. 41, pp. 136-147.

Tabash, M.I. and Dhankar, R.S. (2014), "Islamic financial development and economic growthempirical evidence from United Arab Emirates", Journal of Emerging Economies and Islamic Research, Vol. 2 No. 3, pp. 1-16.

Thumrongvit, P., Kim, Y. and Pyun, C.S. (2013), "Linking the missing market: the effect of bond markets on economic growth", International Review of Economics and Finance, Vol. 27, pp. 529-541.

Ullah, A. (Ed.), (1989) Semiparametric and Nonparametric Econometrics, Physica-Verlag Heidelberg. doi: 10.1007/978-3-642-51848-5.

Yıldırım, S., Yıldırım, D.C. and Diboglu, P. (2020), "Does Sukuk market development promote economic growth?”, PSU Research Review, Emerald Publishing, Vol. 4 No. 3, pp. 209-218, doi: 10.1108/ PRR-03-2020-0011.

Zhang, K.H. (2001), "Does foreign direct investment promote economic growth? Evidence from east Asia and Latin America”, Contemporary Economic Policy, Vol. 19 No. 2, pp. 175-185.

\section{Corresponding author}

Mohammed Ayoub Ledhem can be contacted at: ledhem.edu@gmail.com

For instructions on how to order reprints of this article, please visit our website:

www.emeraldgrouppublishing.com/licensing/reprints.htm

Or contact us for further details: permissions@emeraldinsight.com 